\title{
BILATERÁLNE ZMLUVY SLOVENSKEJ REPUBLIKY O SPOLUPRÁCI A VZÁJOMNEJ POMOCI PRI KATASTROFÁCH
}

\section{BILATERAL TREATIES OF THE SLOVAK REPUBLIC ON COOPERATION AND MUTUAL ASSISTANCE IN THE EVENT OF DISASTER}

\author{
Lucia Bódišová \\ Univerzita Pavla Jozefa Šafárika v Košiciach, Právnická fakulta \\ https://doi.org/10.33542/SIC2019-1-05
}

\begin{abstract}
ABSTRAKT
Bilaterálne zmluvy sú dôležitou súčastou medzinárodného práva reakcie na katastrofy, ktoré čiastočne vyplñ̆ajú absenciu kodifikačného dohovoru komplexne upravujúceho aktivity subjektov pôsobiacich vo všetkých štádiách katastrof. ${ }^{l}$ Slovenská republika od svojho vzniku uzatvára bilaterálne zmluvy o dobrovolnom poskytovani pomoci pri katastrofách, živelných pohromách a iných mimoriadnych udalostiach, ktoré ohrozujú životy a zdravie l'udi, majetok alebo životné prostredie a určujú základné podmienky pomoci poskytovanej na základe písomnej žiadosti zmluvnej strany žiadajúcej o pomoc. Ciel'om prispevku je poukázat' na medzinárodné aspekty prírodných a l'udskou činnost'ou spôsobených katastrof, ktoré sú upravené v bilaterálnych zmluvách Slovenskej republiky o spolupráci a vzájomnej pomoci pri katastrofách a na rozsah ich úpravy.
\end{abstract}

\begin{abstract}
Bilateral treaties are an important part of International Disaster Response Law, which partially fills in the gap that exists due to the absence of a convention that comprehensively regulates the activities of entities active at all stages of disasters. Since its inception, the Slovak Republic has concluded bilateral treaties regulating voluntary provision on assistance in the event of disasters, natural disasters and other extraordinary situations threatening lives and health of people, property or the environment, and determine the basic conditions of assistance provided at the written request of the requesting State Party. The aim of the paper is to point out international aspects of natural and man-made disasters, which are regulated in the bilateral treaties of the Slovak Republic on cooperation and mutual assistance in the event of disasters, and the extent of their regulation.
\end{abstract}

\section{I. ÚVOD}

Katastrofy, či už prírodné alebo spôsobené l'udskou činnost'ou, závažným spôsobom zasahujú do fungovania spoločnosti a predstavujú negatívny fenomén, ktorý s narastajúcim vplyvom klimatických zmien má čoraz väčší vplyv na udržatel'ný rozvoj a prosperitu štátov. Údaje z poslednej dekády uvádzajú, že každoročne dochádza v priemere ku 354 katastrofám, ktoré si

Príspevok bol spracovaný v rámci riešenia projektu VVGS-2018-945: „Návrh metodického postupu mimovládnych organizácií v prípade katastrofy v podmienkach Slovenskej republiky.“ 
vyžiadajú vyše 70000 obetí na l’udských životoch a ekonomické škody za vyše 153 miliárd amerických dolárov. ${ }^{2}$ Žiadny štát nie je imúnny voči výskytu katastrof a to platí aj v prípade Slovenskej republiky (d’alej aj „SR“), ktorá je z hl'adiska druhu katastrof najvýraznejšie ovplyvnená náhlymi prírodnými katastrofami, konkrétne prívalovými povodňami, zosuvmi pôdy, suchom, požiarmi, veternými smršt’ami a snehovými kalamitami. Je potrebné podotknút', že na území SR nedochádza častokrát k výskytu katastrof, ktoré možno vymedzit' ako kalamitnú udalost' alebo sériu udalostí, ktoré majú za následok rozsiahle straty na l'udských životoch, vel'ké l'udské utrpenie a tieseň, masové presídlenie alebo rozsiahle materiálne alebo environmentálne škody, ktoré vážne narušujú fungovanie spoločnosti. ${ }^{3}$

Napriek tomu SR nie je l'ahostajná problematika katastrof, čo sa prejavuje okrem iného v uzatváraní bilaterálnych zmlúv, ktoré spolu s multilaterálnymi a regionálnymi zmluvami, ako aj právne nezáväznými dokumentmi formujú novovytvárajúce sa odvetvie medzinárodného práva - medzinárodné právo reakcie na katastrofy (d’alej aj „IDRL“). ${ }^{4}$ Zmluvný systém SR pre mimoriadne udalosti je tvorený zmluvami o spolupráci a vzájomnej pomoci pri katastrofách, ale aj zmluvami o spolupráci ${ }^{5}$ a v určitom ohl'ade aj zmluvami o medzinárodnej cestnej doprave, ${ }^{6}$ ktoré nepriamo upravujú vybrané aspekty katastrof.

Ciel'om príspevku je poukázat' na medzinárodné aspekty prírodných a l’udskou činnostou spôsobených katastrof, ktoré sú upravené v bilaterálnych zmluvách SR o spolupráci a vzájomnej pomoci pri katastrofách a na rozsah ich úpravy. Bilaterálne zmluvy SR o spolupráci a vzájomnej pomoci pri katastrofách sú v prevažnej miere uzatvorené so susednými štátmi, ale aj s Bieloruskom, Čiernou Horou, Chorvátskom, Ruskou Federáciou, Slovinskom a Srbskom.

\section{BILATERÁLNE ZMLUVY O SPOLUPRÁCI A VZÁJOMNEJ POMOCI PRI KA- TASTROFÁCH}

\section{Postavenie bilaterálnych zmlúv o spolupráci a vzájomnej pomoci pri katastrofách v medzinárodnom práve reakcie na katastrofy}

2 CRED CRUNCH: Natural disasters in 2017: Lower mortality, higher cost, Issue No. 50, Centre for Research on the Epidemiology of Disasters, Université catholique de Louvain Brussels, Belgium, 2018. Dostupné online: https://www.emdat.be. (cit. 15.11.2018).

3 UN GENERAL ASSEMBLY: Report of the International Law Commission, 2016, A/71/10, kapitola IV - Protection of persons in the event of disasters, str. 21, ISSN: 0251-822X. Dostupné online: http://legal.un.org/docs/?path=../ilc/reports/2016/english/a_71_10.pdf\&lang=EFSRAC (cit. 15.11.2018).

4 Zahraničná literatúra medzinárodné právo reakcie na katastrofy označuje ako „International Disaster Response Law.“

5 Medzi zmluvy o spolupráci autor zarad'uje Zmluvu medzi Slovenskou republikou a Českou republikou o úprave režimu a o spolupráci na spoločných štátnych hraniciach, zverejnená v Zbierke zákonov ako Oznámenie Ministerstva zahraničných vecí Slovenskej republiky č. 195/1993 Z.z. o uzavretí Zmluvy medzi Slovenskou republikou a Českou republikou o úprave režimu a o spolupráci na spoločných štátnych hraniciach, čl.18; Zmluva medzi Slovenskou republikou a Ukrajinou o dobrom susedstve, priatel'ských vztahoch a spolupráci, zverejnená v Zbierke zákonov ako Oznámenie Ministerstva zahraničných vecí Slovenskej republiky č. 177/1994 Z.z. o uzavretí Zmluvy medzi Slovenskou republikou a Ukrajinou o dobrom susedstve, priatel'ských vzt’ahoch a spolupráci, čl. 12; Dohodu medzi vládou Slovenskej republiky a vládou Mad’arskej republiky o cezhraničnej spolupráci medzi územnými celkami alebo orgánmi, zverejnená v Zbierke zákonov ako Oznámenie Ministerstva zahraničných vecí Slovenskej republiky č. 4/2002 Z.z. o podpísaní Dohody medzi vládou Slovenskej republiky a vládou Mad’arskej republiky o cezhraničnej spolupráci medzi územnými celkami alebo orgánmi, čl. 5 .

6 Medzi bilaterálne zmluvy o medzinárodnej cestnej preprave, ktoré sú aplikovatel'né v prípade katastrofy autor zarad’uje Dohodu medzi vládou Slovenskej republiky a vládou Lotyšskej republiky o medzinárodnej cestnej preprave, zverejnená v Zbierke zákonov ako Oznámenie Ministerstva zahraničných vecí Slovenskej republiky č. 87/2000 Z.z. o uzavretí Dohody medzi vládou Slovenskej republiky a vládou Lotyšskej republiky o medzinárodnej cestnej preprave, čl. 8; Dohodu medzi vládou Slovenskej republiky a vládou Holandského královstva o medzinárodnej cestnej preprave, zverejnená v Zbierke zákonov ako Oznámenie Ministerstva zahraničných vecí Slovenskej republiky č. 105/2000 Z.z. o uzavretí Dohody medzi vládou Slovenskej republiky a vládou Holandského král'ovstva o medzinárodnej cestnej preprave, čl. 3. Dohodu medzi vládou Slovenskej republiky a vládou Moldavskej republiky o medzinárodnej cestnej preprave osôb a nákladov, zverejnená v Zbierke zákonov ako Oznámenie Ministerstva zahraničných vecí Slovenskej republiky č. 421/2000 Z.z. o uzavretí Dohody medzi vládou Slovenskej republiky a vládou Moldavskej republiky o medzinárodnej cestnej preprave osôb a nákladov, čl. 8 . 
Medzinárodné spoločenstvo v dôsledku vysokého výskytu prírodných a l’udskou činnost'ou spôsobených katastrof sa čoraz intenzívnejšie podiel'a na formovaní nového odvetvia medzinárodného práva verejného - IDRL, ktorého ciel'om je ul'ahčit' poskytovanie medzinárodnej pomoci a spolupráce počas jednotlivých štádií katastrof. Základom tohto odvetvia sú normy, pravidlá a princípy pre medzinárodnú humanitárnu pomoc v dôsledku katastrof v čase mieru, ktoré sú prírodnej, technologickej alebo priemyselnej povahy. Normy IDRL sú inšpirované predovšetkým tromi oblast’ami medzinárodného práva verejného, a to medzinárodným humanitárnym právom, medzinárodným právom $\mathrm{v}$ oblasti l'udských práv a medzinárodným utečeneckým právom. Na rozdiel of medzinárodného humanitárneho práva, IDRL sa aplikuje na neúmyselné katastrofy v kontexte mierovej spolupráce, kedy štáty alebo medzivládne humanitárne alebo iné organizácie ponúkajú, žiadajú, poskytujú alebo prijímajú cezhraničnú humanitárnu pomoc. ${ }^{7} A n-$ drea de Guttry nadväzuje na túto definíciu a dodáva, že „táto definícia je len čiastočne uspokojivá, pretože sa týka najmä akútnej fázy katastrof a nezahŕňa iné aspekty, ktoré sa v poslednom čase stali čoraz dôležitejšími, ako napríklad prevencia katastrof, zníženie rizika vzniku katastrof, vytvorenie prostredia potrebného na zníženie rizika katastrof, ako aj tie opatrenia, ktoré sú späté s obnovou. “8 Tento vývoj v úprave jednotlivých štádií katastrof možno pozorovat’ aj v bilaterálnych zmluvách o spolupráci a vzájomnej pomoci pri katastrofách, ktoré v čoraz väčšom rozsahu upravujú aktivity súvisiace, predovšetkým, so znižovaním rizika katastrof a zefektívnením spolupráce medzi zmluvnými stranami.

\subsection{Historický vývoj bilaterálnych zmlúv tvoriacich medzinárodné právo reakcie na ka- tastrofy}

Súčasná podoba IDRL je ovplyvnená ohromným množstvom bilaterálnych zmlúv, ktoré upravujú široké spektrum medzinárodných aspektov prírodných a l'udskou činnost'ou spôsobených katastrof. Ich obsah je ovplyvnený troma etapami tvorby. Prvú etapu možno ohraničit' obdobím 50. až 60. rokov 20. storočia. Pre tieto zmluvy je typické, že upravovali iba určité aspekty katastrof. Príkladom takýchto zmlúv sú zmluvy uzatvorené Spojenými štátmi americkými s Indiou, Peru či Japonskom o poskytovaní medzinárodnej pomoci. ${ }^{9}$ Hlavným ciel’om týchto zmlúv bolo ul'ahčit' proces dovozu a prijímania pomoci. Typickým ustanovením zmlúv tejto etapy je oslobodenie predmetov pomoci od povinnosti zaplatit' clo a dane.

V rámci druhej etapy tvorby bilaterálnych zmlúv (70. roky 20. storočia) štáty začali uzatvárat' zmluvy, pre ktoré je charakteristický komplexný systém vzájomnej pomoci v prípade prírodnej alebo l'udskou činnost'ou spôsobenej katastrofy. Vznik týchto zmlúv je spätý najmä s spôsobením Rady Európy, ktorá iniciovala a podporovala vznik pravidiel na prevenciu a ochranu pred rozsiahlymi katastrofami a organizáciu záchranných operácií. Pre toto obdobie je taktiež príznačné uzatváranie zmlúv o cezhraničnej spolupráci ${ }^{10}$, ktoré upravovali väčšinu aspektov katastrof.

7 REINECKE, I.: International Disaster Response Law and the Coordination of International Organisations, The Australian National University Undergraduate Research Journal, Vol. 2, 2010, str. 145 - 146. Dostupné online: http://pressfiles.anu.edu.au/downloads/press/n1676/pdf/ch09.pdf (cit. 15.11.2018).

8 DE GUTTRY, A., GESTRI, M., VENTURINI, G.: International Disaster Response Law, T.M.C. Asser Press, 2012, str. 6, ISBN: 978-90-6704-881-1.

9 Pozri: Exchange of Notes Consulting on Agreement Relating to Emergency Flood Relief Assistance, 27. september 1956, 281 United Nations Treaty Series, str. 289; Exchange of Notes Consulting on Agreement Relating to Surplus Agricultural Commodities for the Drought Relief, 17. apríl a 4. - 8. máj 1956, 278 United Nations Treaty Series, str. 117; Exchange of Notes Consulting on Agreement Relating to Emergency Flood Relief Assistance, 12. november 1959, 361 United Nations Treaty Series, str. 27.

${ }^{10}$ Pozri: Agreement on Mutual Assistance in the Event of Disasters or Serious Accidents, 3. február 1977, 1214 United Nations Treaty Series, str. 67; Convention on Mutual Assistance in the Event of Disasters or Serious Accidents, 21. apríl 1981, 1437 United Nations Treaty Series, str. 33; Agreement on Mutual Assistance in the Event of Disasters or Serious Accidents, 28. október 1984. 
Tretia etapa tvorby bilaterálnych zmlúv je vymedzená obdobím od 90. rokov 20. storočia až po súčasnost', v ktorej prevláda prijímanie zmlúv obsahujúcich nielen komplexnú cezhraničnú spoluprácu, ale aj zásady poskytovania medzinárodnej pomoci, ktoré možno vyvodit' z jednotlivých ustanovení zmlúv. Základnými zásadami, ktoré sa uplatňujú v IDRL pri poskytovaní medzinárodnej pomoci, predovšetkým s ohl'adom na ochranu osôb, sú zásada humanity, neutrality, nestrannosti a nediskriminácie, pri zohl'adnení potrieb obzvlášt' zranitel'ných skupín obyvatel'stva. ${ }^{11}$ Vplyvom Medzinárodnej dekády pre zníženie prírodných katastrof ${ }^{12}$ došlo k zmene obsahu zmlúv a to tým, že sa vo väčšej miere vyskytujú ustanovenia o znížení rizika vzniku katastrof, ale aj zintenzívnenia spolupráce medzi štátmi v rámci spoločných vzdelávacích programov a cvičení. ${ }^{13}$

Normy novoprijatých prameňov IDRL sa častokrát inšpirujú existujúcimi bilaterálnymi zmluvami o spolupráci a pomoci pri katastrofách. Ako príklad možno uviest' Usmernenia IDRL pre vnútroštátne ul'ahčenie a reguláciu medzinárodnej pomoci a na ich základe prijatý Modelový zákon na ul’ahčenie a reguláciu medzinárodnej pomoci pri odstraňovaní následkov katastrof a počiatočnej pomoci pri obnove či nedávno prijatý Návrh článkov o ochrane osôb v prípade katastrof. Spomínané dokumenty preberajú právnu úpravu týkajúcu sa udelenia súhlasu s poskytovaním medzinárodnej pomoci, či obmedzenia právnych prekážok, ktorým by za bežných okolností čelili záchranné jednotky, ich výbava, či predmety slúžiace na zmiernenie následkov katastrof.

\section{Druhy bilaterálnych zmlúv medzinárodného práva reakcie na katastrofy}

Bilaterálne zmluvy IDRL možno rozlišovat' na základe viacerých kritérií. Z hl’adiska subjektov uzatvárajúcich bilaterálnu zmluvu ich možno rozlišovat' na zmluvy uzatvorené medzi štátmi a na zmluvy medzi štátom a medzinárodnou humanitárnou organizáciou, ktoré sú známe aj ako zmluvy o štatúte a najčastejšie upravujú sídlo medzinárodnej organizácie alebo realizáciu jej programov na území štátu. Zmluvy, ktoré uzatvárajú štáty s mimovládnymi organizáciami sú regulované vnútroštátnym právom. Zvyčajne upravujú oblast' koordinácie s vládnymi orgánmi, slobodu pohybu v rámci územia postihnutého štátu, zrieknutie sa alebo redukcia povinností v súvislosti s clami, vstupom záchranného personálu na územie štátu a pod. V rámci bilaterálnych zmlúv sa stretávame aj so zmluvami o poskytnutí grantu, ktoré sú určené na poskytnutie medzinárodnej pomoci.

Z hl'adiska typológie katastrof možno bilaterálne zmluvy rozlišovat' na tie, ktoré regulujú všetky druhy prírodných a/alebo l'udskou činnost'ou spôsobených katastrof, alebo ktoré sú aplikované iba na konkrétny druh katastrofy, ako napr. na požiare lesných porastov, zemetrasenia a pod. Okrem toho sa bilaterálne zmluvy IDRL môžu vzt'ahovat' iba na určitý aspekt (napr. poskytnutie predmetov medzinárodnej pomoci) alebo oblast' (napr. medzinárodnú dopravu, cezhraničnú spoluprácu) ${ }^{14}$ prípadne upravujú komplexné poskytovanie medzinárodnej pomoci

11 UN GENERAL ASSEMBLY: Report of the International Law Commission, 2016, A/71/10, kapitola IV - Protection of persons in the event of disasters, str. 33, ISSN: 0251-822X. Dostupné online: http://legal.un.org/docs/?path=../ilc/reports/2016/english/a_71_10.pdf\&lang=EFSRAC (cit. 15.11.2018).

12 Pre viac k Medzinárodnej dekáde pre zníženie prírodných katastrof pozri: UNISDR: International Decade for Natural Disaster Reduction programme forum 1999 - proceedings, 1999. Dostupné online: https://www.unisdr.org/we/inform/publications/31468 (cit. 15.11.2018).

13 FISHER, H.: International disaster response law treaties: trends, patterns and lacunae, In: International disaster response laws, principles and practice: reflections, prospects and challenges, International Federation of Red Cross and Red Crescent, Ženeva, 2003, str. 25 - 30. Dostupné online: http://www.ifrc.org/PageFiles/41194/idrl-book-c2.pdf (cit. 15.11.2018).

14 Pre viac pozri: Oznámenie Ministerstva zahraničných vecí Slovenskej republiky č. 195/1993 Z.z. o uzavretí Zmluvy medzi Slovenskou republikou a Českou republikou o úprave režimu a o spolupráci na spoločných štátnych hraniciach; Oznámenie Ministerstva zahraničných vecí Slovenskej republiky č. 4/2002 Z.z. o podpísaní Dohody medzi vládou Slovenskej republiky a vládou Mad'arskej republiky o cezhraničnej spolupráci medzi územnými celkami alebo orgánmi; Oznámenie Ministerstva zahraničných vecí Slovenskej republiky č. 87/2000 Z.z. o uzavretí Dohody medzi vládou Slovenskej republiky a vládou Lotyšskej republiky o medzinárodnej cestnej preprave; Oznámenie Ministerstva zahraničných vecí Slovenskej republiky č. 
a spolupráce, ${ }^{15}$ ako je tomu v prípade bilaterálnych zmlúv o spolupráci a vzájomnej pomoci pri katastrofách. V tomto článku budeme venovat' pozornost' iba bilaterálnym zmluvám, ktoré uzatvorila SR s inými štátmi, a ktoré obsahujú komplexnú úpravu vzájomnej spolupráce a pomoci pri katastrofách.

\subsection{Bilaterálne zmluvy o vzájomnej pomoci a spolupráci pri katastrofách}

Pre bilaterálne zmluvy o vzájomnej pomoci a spolupráci, ktoré sú uzatvorené medzi štátmi je príznačné, že obsahujú právnu úpravu iniciácie a ukončenia medzinárodnej pomoci, hlavných kontaktných miest na výmenu príslušných informácií, spôsobu prekračovania štátnych hraníc a pobytu na území štátu postihnutého katastrofou. Ďalej upravujú spôsob dovozu, vývozu a prepravy výbavy a predmetov pomoci alebo použitie lietadiel. Kl'účovými ustanoveniami sú tie, ktoré sa vzt'ahujú na koordináciu a riadenie záchranných činností, náhradu výdavkov za poskytnutú pomoc alebo náhrady škody v prípade ujmy na zdraví člena záchrannej jednotky alebo v prípade straty, či poškodenia majetku. Niektoré zmluvy upravujú aj podmienky spolupráce pri prevencii katastrof, ako aj pri iných formách vzájomnej spolupráce, kde ako príklad možno uviest' informovanie o vzniku katastrofy, ktorej následky sa šíria na územie štátu druhej zmluvnej strany, či vykonávanie spoločných cvičení príslušníkov civilnej ochrany. Dôležitou formou spolupráce, hoci je prítomná v bilaterálnych zmluvách iba sporadicky, je vytváranie predpokladov na spoluprácu národných humanitárnych organizácií pri poskytovaní pomoci, ktorá má významný dopad na ul’ahčenie, koordináciu a kvalitu poskytovanej pomoci. Taktiež výnimočne sa stretávame aj s vytvorením spoločných komisií, ktorých úlohami je napr. organizácia činností súvisiacich s vykonávaním dohody, riešenie konkrétnych organizačných a technických problémov, určenie pravidiel vzájomnej komunikácie, či riešenie sporov súvisiacich s výkonom zmluvy. ${ }^{16}$

\section{BILATERÁLNE ZMLUVY O SPOLUPRÁCI A VZÁJOMNEJ POMOCI UZA- TVORENÉ SLOVENSKOU REPUBLIKOU}

Slovenská republika od svojho vzniku uzatvorila jedenást’ bilaterálnych zmlúv o spolupráci a vzájomnej pomoci pri katastrofách. ${ }^{17} \mathrm{Z}$ historického pohl’adu sú analyzované zmluvy výsledkom tzv. , tretej vlny“ tvorby bilaterálnych zmlúv v oblasti IDRL. Bilaterálne zmluvy SR o vzájomnej spolupráci a pomoci možno označit’ za rámcové zmluvy, ktorých jednotlivé ustanovenia sa od seba odlišujú v závislosti od vzt’ahu medzi konkrétnymi zmluvnými stranami.

\section{Poskytovanie medzinárodnej pomoci v prípade katastrof}

K uplatneniu bilaterálnej zmluvy o spolupráci a vzájomnej pomoci pri katastrofách je nevyhnutné, aby došlo ku vzniku katastrofy, živelnej pohromy alebo inej mimoriadnej udalosti, ktorá ohrozuje životy a zdravie l'udí, majetok alebo životné prostredie. Štáty, ako aj neštátni aktéri neváhajú v takýchto situáciách prijat’ žiadost' o pomoc od štátu, ktorý bol postihnutý ka-

421/2000 Z.z. o uzavretí Dohody medzi vládou Slovenskej republiky a vládou Moldavskej republiky o medzinárodnej cestnej preprave osôb a nákladov.

15 Pre viac pozri: Oznámenie Ministerstva zahraničných vecí Slovenskej republiky č. 165/2012 Z.z. o uzavretí Dohody medzi vládou Slovenskej republiky a vládou Srbskej republiky o spolupráci a vzájomnej pomoci pri mimoriadnych udalostiach; Oznámenie Ministerstva zahraničných vecí Slovenskej republiky č. 373/1998 Z.z. o uzavretí Zmluvy medzi Slovenskou republikou a Rakúskou republikou o spolupráci a vzájomnej pomoci pri katastrofách.

16 Pozri napr. Oznámenie Ministerstva zahraničných vecí Slovenskej republiky č. 315/1997 Z.z. o uzavretí Dohody medzi vládou Slovenskej republiky a vládou Mad’arskej republiky o spolupráci a vzájomnej pomoci pri katastrofách, čl. 14.

17 Bilaterálne zmluvy vo svojom názve častokrát namiesto pojmu „katastrofa“ uvádzajú pojem „mimoriadna udalost”, ktorý autor na základe definícií uvedených zmluvách považuje za synonymum. 
tastrofou alebo z vlastnej iniciatívy ponúknut' pomoc, najmä v prípadoch, ked'štát nemá dostatočné kapacity na vyrovnanie sa s jej následkami. Žiadost' o pomoc alebo ponuku medzinárodnej pomoci, v prípade bilaterálnych zmlúv SR, spravidla predkladá a prijíma minister vnútra konkrétnej zmluvnej strany. V žiadosti o pomoc sa najčastejšie uvádza druh, formu a rozsah požadovanej pomoci, prípadne kontaktné body a osoby a návrh o spôsobe poskytnutia pomoci. Je zvykom, že žiadost' alebo ponuka medzinárodnej pomoci sa podáva písomne v úradnom jazyku zmluvných strán alebo v anglickom jazyku. V prípade, že je žiadost' podaná ústne, musí byt' dodatočne písomne potvrdená.

\subsection{Súhlas s poskytnutím medzinárodnej pomoci}

Ako je príznačné pre IDRL, pred poskytnutím medzinárodnej pomoci je nevyhnutné obdržat' súhlas štátu prijímajúceho pomoc, ktorý predstavuje základnú podmienku na to, aby subjekty aktívne sa podiel'ajúce na reakcii na katastrofy poskytli postihnutému štátu pomoc. Vyjadruje to mnoho medzinárodných prameňov ako napr. rezolúcia VZ OSN 46/182, ktorá konštatuje, že „humanitárna pomoc má byt' poskytovaná so súhlasom dotknutého štátu a na zásade jeho odvolatel'nosti." ${ }^{18}$ Dôvodom takéhoto konania je rešpektovanie primárnej úlohy štátu postihnutého katastrofou, ktoré je založené na dlhodobom uznaní medzinárodného práva, že štát vie najlepšie posúdit' závažnost' tej-ktorej katastrofy a taktiež skutočnost', že pri poskytovaní medzinárodnej pomoci je nevyhnutné rešpektovat' suverenitu štátu postihnutého katastrofou, ktoré predstavuje ústredný princíp aplikovatel'ný pri reakcii na katastrofy. Avšak ako atribút rovnosti medzi štátmi, suverenita nepredstavuje neobmedzenú slobodu, ale podlieha povinnosti dodržiavat' medzinárodné záväzky. Princíp suverenity by sa preto nemal považovat' za právnu prekážku, ktorá bráni medzinárodnej humanitárnej pomoci, ale ako nevyhnutnú podmienku na uskutočnenie spolupráce, ktorá sa vyžaduje medzi štátmi v humanitárnych situáciách. ${ }^{19}$

Súhlas s medzinárodnou pomocou môže štát odmietnut' udelit'. Dvoma hlavnými dôvodmi, prečo štáty odmietajú medzinárodnú pomoc je obava, že pomoc bude použitá ako zámienka na politické zasahovanie do vnútorných záležitostí štátu alebo, že prijatie pomoci bude vnímané domácim obyvatel'stvom ako politická slabost' či nekompetentnost'. ${ }^{20}$ Súhlas nemožno však odopriet' zo svojvol'ných dôvodov. Medzinárodná pomoc podliehajúca súhlasu dotknutého štátu musí byt' $v$ súlade $\mathrm{s}$ medzinárodným a vnútroštátnym právom a súčasne má reflektovat' potreby osôb dotknutých katastrofou a spĺn̆at' určité kvalitatívne parametre. Štáty majú v tomto ohl'ade právo určit' druh, rozsah a podmienky pre požadovanú pomoc. Podmienky by nemali byt' stanovené svojvol'ne, ale s ohl'adom na ochranu obetí a môžu zahŕňat' obmedzenia založené napr. na bezpečnosti, výžive alebo kultúrnej vhodnosti. Zmluvné strany najčastejšie poskytujú pomoc vyslaním záchranných jednotiek, odborníkov, poskytnutím výbavy a predmetov pomoci alebo potrebných informácií.

\subsection{Koordinácia a riadenie medzinárodnej pomoci}

S poskytnutím medzinárodnej pomoci je oddelitel'ne spätá koordinácia a riadenie záchranných operácií, ktorá je vykonávaná príslušnými orgánmi zmluvnej strany žiadajúcej o pomoc

18 UN GENERAL ASSEMBLY: Strengthening of the coordination of humanitarian emergency assistance of the United Nations, 19. december 1991, A/RES/46/182, článok 3.

Dostupné online: http://www.un.org/documents/ga/res/46/a46r182.htm (cit. 15.11.2018).

19 MACALISTER-SMITH P.: Disaster Relief: Reflections on the Role of International Law, Max-Planck-Institut für ausländisches öffentliches Recht und Völkerrecht, 1985, str. 31.

Dostupné online: http://www.zaoerv.de/45_1985/45_1985_1_a_25_43.pdf (cit. 15.11.2018).

20 THOMSEN, M.: The Obligation not to Arbitrarily Refuse International Disaster Relief: A Question of Sovereignty, Melbourne Journal of International Law, Vol. 16, 2015, str. 4. Dostupné online: http://law.unimelb.edu.au/data/assets/pdf_file/0008/1687787/Thomsen.pdf (15.11.2018). 
v súlade s právnymi predpismi, ktoré platia na jej území. V podmienkach SR a na základe bilaterálnych zmlúv sú príslušnými orgánmi oprávnenými na riadenie a koordináciu prác spravidla ministerstvá vnútra zmluvných strán. Úlohy záchranným jednotkám sa odovzdávajú len prostredníctvom ich velitel'ov alebo vedúcich a distribúciu predmetov medzinárodnej pomoci je zodpovedný štát prijímajúci pomoc. Na druhej strane, príslušné orgány zmluvnej strany žiadajúcej o pomoc poskytujú záchranným jednotkám a jednotlivým vyslaným odborníkom pomoc a ochranu, ktorá môže byt' vo forme poskytnutia ubytovania, stravy alebo nevyhnutnej lekárskej pomoci. ${ }^{21}$

\section{Eliminácia právnych prekážok pri poskytovaní medzinárodnej pomoci}

V prípade, že štát postihnutý katastrofou udelí súhlas ponúkanej medzinárodnej pomoci, ktorá splńa stanovené podmienky, má prijat' vhodné opatrenia v rámci svojho vnútroštátneho práva na zabezpečenie promptnej a efektívnej pomoci. S poskytnutím pomoci je neoddelitel'ne spojené prekračovanie štátnej hranice, ktoré patrí k ustanoveniam najviac zvýrazňujúcim vzt'ah medzi zmluvnými stranami. Prevažná čast' bilaterálnych zmlúv SR o vzájomnej spolupráci a pomoci pri katastrofách vyžaduje preukázanie totožnosti len od velitel'a alebo vedúceho záchrannej jednotky prostredníctvom preukazu totožnosti alebo služobného preukazu. Ostatní členovia záchrannej jednotky sú uvedení na zozname, ktorý pri preukazovaní totožnosti predkladá príslušným orgánom velitel' alebo vedúci záchrannej jednotky. Vedúci a členovia záchrannej jednotky spravidla nepotrebujú víza, povolenie na pobyt, či pracovné povolenie. Výnimkou v tejto oblasti je zmluva s Bieloruskou republikou, ktorá požaduje, aby členovia záchrannej jednotky a odborníci mali platný cestovný doklad, vízum, zdôvodnený účel a podmienky plánovaného pobytu a majú dostatočné prostriedky na živobytie na dížku plánovaného pobytu a na návrat do štátu poskytujúceho pomoc. Navyše nesmie íst' o osoby, na ktoré bolo vydané vo vnútroštátnych databázach štátov zmluvných strán upozornenie na účely odopretia vstupu a nepokladajú sa za hrozbu pre verejný poriadok, vnútornú bezpečnost', verejné zdravie alebo medzinárodné vzt’ahy štátov zmluvných strán. ${ }^{22} \mathrm{Na}$ členov záchranných jednotiek sa počas ich pobytu na území zmluvnej strany žiadajúcej o pomoc vzt'ahujú vnútroštátne právne predpisy tejto zmluvnej strany.

V rámci eliminácie právnych prekážok pri poskytovaní medzinárodnej pomoci sa zmluvné strany bilaterálnych zmlúv o spolupráci a vzájomnej pomoci sa zaväzujú ul'ahčit' prepravu výbavy a predmetov pomoci cez štátnu hranicu. To sa prejavuje najmä oslobodením od cla, daní a iných poplatkov, ako aj nevyžadovaním povolenia na medzinárodnú cestnú prepravu pre vozidlá používané záchrannými jednotkami a pre vozidlá zabezpečujúce prepravu prostriedkov pomoci. Záchranné jednotky okrem výbavy a predmetov pomoci nemôžu vyvážat' ani dovážat' žiadny iný tovar. Ak sa výbava alebo predmety pomoci nespotrebovali alebo nezničili, tak je zmluvná strana poskytujúca pomoc povinná ich vyviezt' spät' na svoje územie. Špeciálne je upravený právny režim omamných a psychotropných látok, ktoré možno doviezt' a použit' len v rámci nevyhnutnej lekárskej pomoci a len kvalifikovaným lekárskym personálom podl'a vnútroštátnych právnych predpisov zmluvnej strany žiadajúcej o pomoc. Nespotrebované omamné a psychotropné látky sa musia vyviezt' spät' na územie zmluvnej strany poskytujúcej pomoc. Dovoz zbraní a munície na územie zmluvnej strany žiadajúcej pomoc je okrem priemyselných trhavín a ich iniciátorov zakázaný.

Zmluvy s Českou a Rakúskou republikou upravujú aj prekračovanie hraníc osobami, ktoré sú ohrozené prírodnou alebo priemyselnou katastrofou. Zmluvné strany sa zaviazali poskytnút'

\footnotetext{
21 Pozri napr. Oznámenie Ministerstva zahraničných vecí Slovenskej republiky č. 315/1997 Z.z., čl. 10, Oznámenie Ministerstva zahraničných vecí Slovenskej republiky č. 374/2004 Z.z., čl. 10.

22 Oznámenie Ministerstva zahraničných vecí a európskych záležitostí Slovenskej republiky č. 212/2017 Z.Z., čl. 6 ods.3.
} 
takýmto osobám pomoc a druhá zmluvná strana sa zaväzuje uhradit' výdavky spojené s poskytnutím pomoci a ich návratom. Podrobnejšie podmienky prechodu a pomoci sú ustanovené v Zmluve medzi Slovenskou republikou a Českou republikou o úprave režimu a o spolupráci na spoločných štátnych hraniciach z roku 1992.

Záchranné operácie $\mathrm{v}$ prípade katastrof si častokrát vyžadujú použitie leteckých prostriedkov, na čo pamätajú aj analyzované zmluvy. Letecké prostriedky sa používajú predovšetkým na presun záchranných jednotiek, ich výbavy, predmetov pomoci a na vykonávanie záchrannej činnosti. Použitie leteckých prostriedkov treba oznámit' príslušným orgánom zmluvnej strany žiadajúcej o pomoc, s uvedením údajov o druhu a označení leteckého prostriedku, o posádke, náklade, čase odletu, predpokladanej trase a mieste pristátia. Lety sa musia uskutočňovat' v súlade s pravidlami ustanovenými každou zmluvnou stranou, ktoré upravujú používanie a navigáciu leteckých prostriedkov počas letov nad jej územím, a postupmi dohodnutými pre prelet štátnej hranice. Osobitná úprava sa vzt’ahuje na použitie vojenských lietadiel, ktoré možno použit' iba so súhlasom zmluvnej strany žiadajúcej o pomoc.

\section{Náhrada výdavkov za poskytnutú pomoc a náhrada škody vzniknutej pri poskytovaní pomoci}

Náhrada výdavkov predstavuje jedno zo základných ustanovení každej zmluvy o spolupráci a pomoci pri katastrofách. Vo všeobecnosti zmluvná strana poskytujúca pomoc nemá voči zmluvnej strane žiadajúcej o pomoc nárok na náhradu výdavkov za poskytnutú pomoc vrátane výdavkov vzniknutých spotrebovaním, poškodením alebo stratou výbavy. Pokial' ide o výdavky na pomoc, ktorú zmluvná strana poskytujúca pomoc len sprostredkúva od právnických osôb alebo fyzických osôb, poskytnutie tejto pomoci si musí zmluvná strana žiadajúca o pomoc priamo vyžiadat' a musí súhlasit' s uhradením nákladov na poskytnutie pomoci. V prípade, že záchranné jednotky počas zásahu alebo v priamej súvislosti s ním spotrebujú svoje zásoby, zmluvná strana žiadajúca o pomoc im ich poskytne v potrebnom rozsahu bezodplatne. Záchranným jednotkám zmluvná strana žiadajúca o pomoc bezodplatne poskytuje aj nevyhnutnú lekársku pomoc. Výnimku z vyššie uvedenej úpravy predstavuje Zmluva s Ruskou federáciou, ktorá ustanovuje, že zmluvná strana žiadajúca o pomoc uhradí zmluvnej strane poskytujúcej pomoc výdavky vynaložené na poskytnutie pomoci, ak sa nedohodnú inak. Navyše zmluvná strana poskytujúca pomoc poistí členov záchranných skupín na poskytnutie pomoci. Poistné bude následne zahrnuté do celkových výdavkov na poskytnutie pomoci. ${ }^{23}$

Pri poskytovaní medzinárodnej pomoci môže dôjst' ku vzniku škody, na čo pamätajú aj bilaterálne zmluvy. Spravidla každá zmluvná strana sa zrieka všetkých nárokov na náhradu škody voči druhej zmluvnej strane v prípade škôd na majetku, ktoré spôsobil člen záchrannej jednotky v súvislosti s poskytovaním pomoci. Každá zmluvná strana sa zrieka všetkých nárokov na náhradu škody voči zmluvnej strane žiadajúcej o pomoc v prípade škôd na zdraví alebo smrti člena záchrannej jednotky, ktorá nastala v súvislosti s poskytovaním pomoci. Ak člen záchrannej jednotky zmluvnej strany poskytujúcej pomoc spôsobí na území zmluvnej strany žiadajúcej pomoc škodu tretej osobe, zodpovednost' za takúto škodu znáša zmluvná strana žiadajúca o pomoc. To však neplatí v prípade, ak škoda bola spôsobená úmyselne alebo $\mathrm{z}$ hrubej nedbanlivosti. Ako v prípade náhrady výdavkov aj v prípade náhrady škody existujú výnimky, ktoré nachádzame v zmluve s Bieloruskou republikou a Ruskou federáciou. Na ich základe zmluvná strana žiadajúca o pomoc nahradí škodu zmluvnej strane poskytujúcej pomoc v prípade ujmy na zdraví alebo v prípade smrti člena záchrannej jednotky alebo odborníka štátu zmluvnej strany poskytujúcej pomoc, alebo v prípade straty alebo poškodenia majetku, ktoré sa vyskytnú

23 Oznámenie Ministerstva zahraničných vecí Slovenskej republiky č. 166/1996 Z.z., čl. 12 ods. 1 a 4. 
počas poskytovania pomoci. ${ }^{24}$ Ak člen záchrannej jednotky alebo odborník štátu zmluvnej strany poskytujúcej pomoc spôsobí na území štátu zmluvnej strany žiadajúcej o pomoc v súvislosti s poskytovaním pomoci škodu tretej osobe, zodpovednost' za škodu nesie zmluvná strana poskytujúca pomoc. $^{25}$

\section{Formy spolupráce medzi zmluvnými stranami v prípade katastrofy}

Ťažiskovým bodom bilaterálnych zmlúv je spolupráca medzi zmluvnými stranami, ktorá môže mat' rôzne podoby, najmä v závislosti od jednotlivých štádí́ katastrof. Posledné roky medzinárodné spoločenstvo venuje značnú pozornost' prijímaniu preventívnych opatrení na elimináciu vzniku katastrof. To sa prejavilo aj v bilaterálnych zmluvách SR, ktoré zaradili tento aspekt do svojich ustanovení. Zmluvné strany sa v nich zaväzujú, že sa budú informovat' o hroziacich katastrofách, podporovat' vzdelávanie a výcvik v ochrane, záchrane a poskytovaní pomoci, výmenu vedeckých a technických informácií dôležitých pri ochrane pred katastrofami, či vývoj a výrobu ochrannej a záchranárskej výbavy. Je dôležité poznamenat', že oblast' prevencie je v zmluvách formulovaná pomerne stroho a všeobecne. Nad rámec spomínaných foriem spolupráce ide zmluva s Ukrajinou, ktorá sa zmieňuje o vypracovaní spoločného systému opatrení na účel prevencie katastrof, či zmluva s Pol'skou republikou, ktorá okrem preventívnych opatrení spomína aj aktivity zmluvných strán v oblasti skúmania príčin katastrof, prípadne vyhl'adávania a identifikácie poškodených osôb a majetku.

Dôležitou formou spolupráce, hoci nie je prítomná v každej bilaterálnej zmluve, je vytváranie predpokladov na spoluprácu národných humanitárnych organizácií pri poskytovaní pomoci, ${ }^{26}$ ktorá má významný dopad na ul'ahčenie, koordináciu a kvalitu poskytovanej pomoci. Potvrdila to aj Hospodárska a sociálna rada OSN v roku 2004, no zároveň upozornila, aby tento nárast aktérov nezasahoval do efektívnosti humanitárnej reakcie, neutrality a nezávislosti humanitárnej pomoci. ${ }^{27}$ Do budúcnosti predpokladáme, že význam medzinárodných medzivládnych, ale aj mimovládnych organizácií v oblasti reakcie na katastrofy bude nad'alej narastat', čo sa prejaví ich pravidelným zapojením do poskytovania medzinárodnej pomoci.

Poskytovanie medzinárodnej pomoci ako aj spolupráca medzi zmluvnými stranami má častokrát ad hoc povahu. Ojedinele bilaterálne zmluvy o spolupráci a vzájomnej pomoci ustanovujú osobitný orgán, ktorého ciel'om je dohliadat' nad výkonom zmluvy. V prípade bilaterálnych zmlúv SR ide o zmluvy, ktoré sú uzatvorené s Mad'arskou republikou, Ruskou federáciou a Ukrajinou, ide o zriadenie Stálej spoločnej komisie (d’alej len „Komisia“). K základným úlohám Komisie patrí, okrem iného: a) organizácia činností súvisiacich s vykonávaním dohody a riešenie konkrétnych organizačných a technických problémov, ktoré z nej vyplývajú; b) určenie pravidiel vzájomnej komunikácie a spôsobu oznamovania hrozby vzniku alebo zániku katastrofy; c) riešenie sporov súvisiacich s výkonom zmluvy. Komisia zvyčajne zasadá raz ročne striedavo na území zmluvných strán. Nakol'ko nedochádza k častému výskytu katastrof ako na území SR, tak na území štátov, s ktorými má SR uzatvorenú zmluvu spolupráci a vzájomnej pomoci, považujeme vytvorenie Komisie za nadbytočné.

\footnotetext{
24 Pozri Oznámenie Ministerstva zahraničných vecí a európskych záležitostí Slovenskej republiky č. 212/2017 Z.z., čl. 12 ods. 1; Oznámenie Ministerstva zahraničných vecí Slovenskej republiky č. 166/1996 Z.z., čl. 13 ods. 1 a 2.

25 Oznámenie Ministerstva zahraničných vecí a európskych záležitostí Slovenskej republiky č. 212/2017 Z.z., čl. 12 ods. 2.

26 Zmienka o národných humanitárnych organizáciách nie je prítomná v zmluvách s Českou republikou, Pol'skou republikou, Rakúskou republikou a Ukrajinou.

27 UN ECONOMIC AND SOCIAL COUNCIL: Strengthening of the coordination of emergency humanitarian assistance of the United Nations, ECOSOC Resolution 2004/50, 23. júl 2004, E/2004/INF/2/Add.2, str. 134. Dostupné online: http://www.ifrc.org/docs/idrl/I577EN.pdf (cit. 15.11.2018).
} 


\section{ZÁVER}

Bilaterálne zmluvy sú dôležitou súčast’ou IDRL, ktoré čiastočne vypĺn̆ajú absenciu kodifikačného dohovoru komplexne upravujúceho aktivity subjektov pôsobiacich vo všetkých štádiách katastrof. Slovenská republika od svojho vzniku uzatvára bilaterálne zmluvy upravujúce spoluprácu a dobrovol'né poskytovanie pomoci pri katastrofách, živelných pohromách a iných mimoriadnych udalostiach, ktoré ohrozujú životy a zdravie l'udí, majetok alebo životné prostredie. Bilaterálne zmluvy SR upravujú základné podmienky pomoci poskytovanej na základe písomnej žiadosti zmluvnej strany žiadajúcej o pomoc. Nakol'ko sú analyzované zmluvy výsledkom tzv. tretej vlny tvorby bilaterálnych zmlúv týkajúcich sa pomoci pri katastrofách, značný priestor je v nich venovaný nadväzovaniu spolupráce, ktorej ciel'om je predchádzat' katastrofám, ako aj zdokonalit' poskytovanie pomoci. Bilaterálne zmluvy SR možno označit' za rámcové zmluvy, ktorých konkrétne ustanovenia závisia od vzt'ahu medzi konkrétnymi zmluvnými stranami. Zmluvy stanovujú postup pre začatie a ukončenie poskytovania pomoci, vyžadujú stanovenie stálych kontaktných miest u zmluvných strán na výmenu príslušných informácií a opisujú spôsoby riadenia záchranných jednotiek, ktoré podliehajú pokynom príslušných orgánov zmluvnej strany žiadajúcej o pomoc. Takisto odrážajú všeobecný zámer zabezpečit' minimalizáciu formalít pri prechode štátnymi hranicami, najmä pokial' ide o upustenie od víz a pracovných povolení pre členov záchranných jednotiek. V prípade tovaru a výbavy určenej na záchranné operácie ide o obmedzenie colných kontrol, oslobodenie od colných poplatkov a daní. Zmluvy zahŕňajú ustanovenia, ktoré rozdel'ujú zodpovednost' za náklady na záchrannú operáciu, ktoré majú byt' znášané štátmi poskytujúcimi pomoc až na výnimku v podobe bilaterálnej zmluvy s Ruskou federáciou. Rovnako bilaterálne zmluvy vyžadujú od zmluvných strán žiadajúcich o pomoc, aby upustili od akýchkol'vek nárokov na náhradu škody, ktorú spôsobili členovia záchranných jednotiek pri poskytovaní pomoci v súvislosti s prírodnou alebo priemyselnou katastrofou. Autor pozitívne hodnotí zaradenie otázky spolupráce národných humanitárnych organizácií pri poskytovaní pomoci, nakol'ko ide o klúčových poskytovatel'ov medzinárodnej pomoci, ktorých význam každým rokom narastá.

Záverom možno konštatovat', že bilaterálne zmluvy o spolupráci a vzájomnej pomoci prispievajú ku koordinovanej a efektívnej medzinárodnej pomoci, ktorá je nevyhnutná k znižovaniu negatívnych dôsledkov katastrof. Je však potrebné dodat', že mechanizmus ustanovený bilaterálnymi zmluvami má v prevažnej miere ad hoc povahu. Za výnimku možno považovat' zmluvy s Mad'arskou republikou, Ukrajinou a Ruskou federáciou, ktoré predpokladajú nadviazanie trvalejšej spolupráce prostredníctvom Stálej spoločnej komisie. Do budúcnosti možno predpokladat', že intenzita uzatvárania bilaterálnych zmlúv bude na ústupe v dôsledku aktívnej úlohy regionálnych organizácií (napr. EÚ, NATO, Rada Európy) pri reakcii na katastrofy.

\section{KLÚČOVÉ SLOVÁ}

Bilaterálne zmluvy, katastrofy, medzinárodná pomoc, medzinárodné právo reakcie na katastrofy, štát

\section{KEY WORDS}

Bilateral Treaties, Disaster, International Assistance, International Disaster Response Law, State

\section{POUŽITÁ LITERATÚRA}

1. CRED CRUNCH: Natural disasters in 2017: Lower mortality, higher cost, Issue No. 50, Centre for Research on the Epidemiology of Disasters, Université catholique de Louvain Brussels, 2018. Dostupné online: https://www.emdat.be. 
2. DE GUTTRY, A., GESTRI, M., VENTURINI, G.: International Disaster Response Law, T.M.C. Asser Press, 2012, ISBN: 978-90-6704-881-1. Dostupné na: https://doi.org/10.1007/978-90-6704-882-8.

3. FISHER D.: Law and Legal Issues in International Disaster Response: A Desk Study, International Federation of the Red Cross and the Red Crescent Societies, Ženeva, 2007. Dostupné online: http://www.ifrc.org/PageFiles/125639/113600-idrl-deskstudy-en.pdf.

4. FISHER H.: International disaster response law treaties: trends, patterns and lacunae, In: International disaster response laws, principles and practice: reflections, prospects and challenges, International Federation of Red Cross and Red Crescent, Ženeva, 2003. Dostupné online: http://www.ifrc.org/PageFiles/41194/idrl-book-c2.pdf.

5. MACALISTER-SMITH P.: Disaster Relief: Reflections on the Role of International Law, Max-Planck-Institut für ausländisches öffentliches Recht und Völkerrecht, 1985. Dostupné online: http://www.zaoerv.de/45_1985/45_1985_1_a_25_43.pdf.

6. Oznámenie Ministerstva zahraničných vecí Slovenskej republiky č. 195/1993 Z.z. o uzavretí Zmluvy medzi Slovenskou republikou a Českou republikou o úprave režimu a o spolupráci na spoločných štátnych hraniciach

7. Oznámenie Ministerstva zahraničných vecí Slovenskej republiky č. 177/1994 Z.z. o uzavretí Zmluvy medzi Slovenskou republikou a Ukrajinou o dobrom susedstve, priatel'ských vzt'ahoch a spolupráci

8. Oznámenie Ministerstva zahraničných vecí Slovenskej republiky č. 166/1996 Z.z. o uzavretí Dohody medzi vládou Slovenskej republiky a vládou Ruskej federácie o spolupráci v oblasti civilnej ochrany a vzájomnej pomoci pri mimoriadnych udalostiach

9. Oznámenie Ministerstva zahraničných vecí Slovenskej republiky č. 315/1997 Z.z. o uzavretí Dohody medzi vládou Slovenskej republiky a vládou Mad’arskej republiky o spolupráci a vzájomnej pomoci pri katastrofách

10. Oznámenie Ministerstva zahraničných vecí Slovenskej republiky č. 373/1998 Z.z. o uzavretí Zmluvy medzi Slovenskou republikou a Rakúskou republikou o spolupráci a vzájomnej pomoci pri katastrofách

11. Oznámenie Ministerstva zahraničných vecí Slovenskej republiky č. 87/2000 Z.z. o uzavretí Dohody medzi vládou Slovenskej republiky a vládou Lotyšskej republiky o medzinárodnej cestnej preprave

12. Oznámenie Ministerstva zahraničných vecí Slovenskej republiky č. 105/2000 Z.z. o uzavretí Dohody medzi vládou Slovenskej republiky a vládou Holandského král'ovstva o medzinárodnej cestnej preprave

13. Oznámenie Ministerstva zahraničných vecí Slovenskej republiky č. 345/2000 Z.z. o podpísaní Dohody medzi vládou Slovenskej republiky a vládou Slovinskej republiky o spolupráci a vzájomnej pomoci pri prírodných a iných katastrofách

14. Oznámenie Ministerstva zahraničných vecí Slovenskej republiky č. 421/2000 Z.z. o uzavretí Dohody medzi vládou Slovenskej republiky a vládou Moldavskej republiky o medzinárodnej cestnej preprave osôb a nákladov

15. Oznámenie Ministerstva zahraničných vecí Slovenskej republiky č. 94/2001 Z.z. o uzavretí Zmluvy medzi Slovenskou republikou a Českou republikou o spolupráci a vzájomnej pomoci pri mimoriadnych udalostiach

16. Oznámenie Ministerstva zahraničných vecí Slovenskej republiky č. 328/2001 Z.z. o prijatí Dohovoru o pomoci v prípade jadrovej havárie alebo radiačnej havárie 
17. Oznámenie Ministerstva zahraničných vecí Slovenskej republiky č. 4/2002 Z.z. o podpísaní Dohody medzi vládou Slovenskej republiky a vládou Mad’arskej republiky o cezhraničnej spolupráci medzi územnými celkami alebo orgánmi

18. Oznámenie Ministerstva zahraničných vecí Slovenskej republiky č. 739/2002 Z.z. o uzavretí Dohody medzi vládou Slovenskej republiky a vládou Pol’skej republiky o spolupráci a vzájomnej pomoci pri katastrofách, živelných pohromách a iných závažných nehodách

19. Oznámenie Ministerstva zahraničných vecí Slovenskej republiky č. 122/2003 Z.z. o uzavretí Dohody medzi vládou Slovenskej republiky a Kabinetom ministrov Ukrajiny o spolupráci a vzájomnej pomoci pri mimoriadnych udalostiach

20. Oznámenie Ministerstva zahraničných vecí Slovenskej republiky č. 374/2004 Z.z. o uzavretí Dohody medzi vládou Slovenskej republikou a vládou Chorvátskej republiky o spolupráci a vzájomnej pomoci pri katastrofách

21. Oznámenie Ministerstva zahraničných vecí Slovenskej republiky č. 92/2005 Z.z. o podpísaní Tamperského dohovoru o poskytovaní telekomunikačných zdrojov na zmiernenie katastrof a záchranné operácie

22. Oznámenie Ministerstva zahraničných vecí Slovenskej republiky č. 165/2012 Z.z. o uzavretí Dohody medzi vládou Slovenskej republiky a vládou Srbskej republiky o spolupráci a vzájomnej pomoci pri mimoriadnych udalostiach

23. Oznámenie Ministerstva zahraničných vecí a európskych záležitostí Slovenskej republiky č. 131/2013 Z.z. o uzavretí Dohody medzi vládou Slovenskej republiky a vládou Čiernej Hory o spolupráci a vzájomnej pomoci pri prírodných a iných katastrofách

24. Oznámenie Ministerstva zahraničných vecí a európskych záležitostí Slovenskej republiky č. 212/2017 Z.z. o podpísaní Dohody medzi vládou Slovenskej republiky a vládou Bieloruskej republiky o spolupráci a vzájomnej pomoci pri mimoriadnych udalostiach

25. REINECKE, I.: International Disaster Response Law and the Coordination of International Organisations, The Australian National University Undergraduate Research Journal, Vol. 2, 2010. Dostupné online:

http://press-files.anu.edu.au/downloads/press/n1676/pdf/ch09.pdf.

26. THOMSEN, M.: The Obligation not to Arbitrarily Refuse International Disaster Relief: A Question of Sovereignty, Melbourne Journal of International Law, Vol. 16, 2015. Dostupné online: http://law.unimelb.edu.au/data/assets/pdf_file/0008/1687787/Thomsen.pdf (15.11.2018).

27. UN ECONOMIC AND SOCIAL COUNCIL: Strengthening of the coordination of emergency humanitarian assistance of the United Nations, ECOSOC Resolution 2004/50, 23. júl 2004, E/2004/INF/2/Add.2. Dostupné online:

http://www.ifrc.org/docs/idrl/I577EN.pdf.

28. UN GENERAL ASSEMBLY: Report of the International Law Commission, 2016, A/71/10, kapitola IV - Protection of persons in the event of disasters, ISSN: 0251-822X. Dostupné online:

29. http://legal.un.org/docs/?path=../ilc/reports/2016/english/a_71_10.pdf\&lang=EFSRAC.

30. UN GENERAL ASSEMBLY: Strengthening of the coordination of humanitarian emergency assistance of the United Nations, 19. december 1991, A/RES/46/182. Dostupné online: http://www.un.org/documents/ga/res/46/a46r182.htm.

\section{KONTAKTNÉ ÚDAJE AUTORA}

Mgr. Lucia Bódišová 
Interný doktorand

Ústav medzinárodného práva a európskeho práva, Právnická fakulta UPJŠ v Košiciach Kováčska 26, P.O.BOX A-45, 04075 Košice

Telefón: +421905889549

E-mail: lucia.bodisova@student.upjs.sk 